\title{
Karakteristik Morfologi Mycobacterium tuberculosis yang Terpapar Obat Anti TB Isoniazid (INH)
}

\author{
Widodo ${ }^{1}$, Agus Irianto ${ }^{2}$ dan Hendro Pramono ${ }^{2}$ \\ ${ }^{1}$ Poltekkes Kemenkes Semarang \\ ${ }^{2}$ Fakultas Biologi, Universitas Jenderal Soedirman, Purwokerto \\ Email : widodo124@ymail.com
}

\begin{abstract}
INH's role in inhibiting the synthesis of mycolic acid which is a component of the cell wall of M. tuberculosis. The experiment research method using a complete randomized experimental design with variations in exposure time 24 hours, 48 hours, 72 hours and 96 hours on INH concentration of $0.5 \mu \mathrm{g} / \mathrm{ml}$ with 6 replications. The results showed influence on each $0.5 \mu \mathrm{g} / \mathrm{ml} \mathrm{INH}$ treatment towards the characteristics of $M$. tuberculosis, at 24 hours of exposure was obtained $18.25 \%$ percentage growth, the average cell size was $1.64 \times 0.35 \mu \mathrm{m}$, the percentage of cell damage was $28.1 \%$. At 48 hours of exposure was obtained $7.9 \%$ percentage of cell growth, the average cell size was $1.64 \mathrm{x}$ $0.36 \mu \mathrm{m}$, the percentage of cell damage was $41 \%$. At 72 hours of exposure was obtained $7.0 \%$ percentage of cell growth, the average cell size was $1.64 \times 0.32 \mu \mathrm{m}$, the percentage of cell damage was $53.4 \%$. At 96 hours of exposure was obtained $1.6 \%$ percentage of cell growth, the average cell size was $1.61 \times 0.29 \mu \mathrm{m}$, the percentage of cell damage was $57 \%$. Morphological changes in cells exposed to $0.5 \mu \mathrm{g} / \mathrm{ml} \mathrm{INH}$ were wrinkles on the cell surface and length shrinkage occur after the regeneration of cells, the cells surface began to become rough and has little damage, the cells experience lysis and the half part of it was oval, the cell's shape changes into cocci. The characteristics of $M$. tuberculosis exposed to INH $0.5 \mathrm{ug} / \mathrm{ml}$ were changes in cell morphology, shorter and change form rods into cocci. However, the morphological changes did not endure permanently in the next generation.
\end{abstract}

Keywords $\quad:$ M. tuberculosis, INH, phenotype.

\begin{abstract}
Abstrak
INH mempunyai peranan dalam menghambat sintesis asam mikolat yang merupakan komponen pembentuk dinding sel M. tuberculosis. Metode penelitian eksperimen dengan menggunakan Rancangan percobaan acak Lengkap dengan variasi waktu pemaparan 24 jam, 48 jam, 72 jam dan 96 jam pada konsentrasi INH 0,5 $\mu \mathrm{g} / \mathrm{ml}$ dengan jumlah ulangan 6. Hasil penelitian menunjukkan ada pengaruh pada masing-masing perlakuan INH $0,5 \mu \mathrm{g} / \mathrm{ml}$ terhadap karakteristik $M$. tuberculosis, pada pemaparan 24 jam diperoleh persentase pertumbuhan $18,25 \%$, ukuran rerata sel $1,64 \times 0,35 \mu \mathrm{m}$, persentase kerusakan sel 28,1\%. Pada pemaparan 48 jam diperoleh persentase pertumbuhan sel $7,9 \%$, ukuran rerata sel $1,64 \times 0,36 \mu \mathrm{m}$, persentase kerusakan sel $41 \%$, pada pemaparan 72 jam diperoleh persentase pertumbuhan sel 7,0\%, ukuran rerata sel $1,64 \times 0,32 \mu \mathrm{m}$, persentase kerusakan sel $53,4 \%$, pada pemaparan 96 jam diperoleh persentase pertumbuhan sel 1,6\%, ukuran rerata sel 1,61 $0,29 \mu$ m, persentase kerusakan sel $57 \%$. Perubahan morfologi sel yang terpapar INH 0,5 $\mu \mathrm{g} / \mathrm{ml}$ pada permukaan sel terjadi kerutan dan penyusutan panjang sel setelah regenerasi, permukaan sel mulai kasar dan sedikit ada kerusakan, sel mengalami lisis dan sebagian sel berbentuk oval, sel mengalami perubahan bentuk menjadi kokus. karakteristik $M$. tuberculosis yang terpapar $\mathrm{INH} 0,5 \mu \mathrm{g} / \mathrm{ml}$ mengalami perubahan morfologi sel, menjadi lebih pendek dan perubahan bentuk dari batang menjadi kokus, namun perubahan morfologi ini tidak terjadi secara permanen pada generasi berikutnya.
\end{abstract}

Kata kunci : M. tuberculosis, INH, Morfologi.

\section{Pendahuluan}

Perkembangan resistensi INH adalah awal munculnya Multi Drung Resistant (MDR) sebagai hasil akuisisi dari mutasi gen untuk target obat yang berbeda, diperberat dengan kasus Human Immunodeficiency Virus HIV dan ketidakpatuhan pasien dalam pengobatan (Rattan et al., 1998). $\mathrm{INH}$ adalah obat yang memerlukan aktivasi oleh katalase atau enzim KatG peroksidase yang dikodekan oleh gen katG, INH menghambat sintesis asam mikolat melalui $\mathrm{NADH}$-protein, reduktase enoil asil dikodekan oleh Inha (Rawat et al., 2003). INH sangat aktif terhadap kompleks MTB (M. tuberculosis, M. bovis, $M$. africanum dan $M$. microti) dengan konsentrasi hambatan minimal
0,02-0,06 mg/ml (Youatt, 1969; Rattan et al., 1998).

Resistensi pada $M$. tuberculosis terjadi secara spontan untuk INH dengan frekuensi 1 dari $10^{5}-10^{6}$ basil per generasi (Zhang et al., 2009). Resistensi $M$. tuberculosis terhadap obat disebabkan karena adanya mutasi gen selain itu karena pengaruh seleksi strain yang resisten selama proses terapi (Kochi et al., 1993). M. tuberculosis resisten secara alami terhadap antibiotik dikaitkan dengan struktur dari dinding sel yang mengandung mikolat sehingga permeabilitas rendah terhadap beragam antibiotik. Hal ini karena porin pada M. tuberculosis tidak mudah dilalui zat terlarut dalam konsentrasi 
rendah dan in aktivasi enzim terhadap obat (Jarlier dan Nikaido, 1994).

Pada penelitian Takayama et al. (1973) dengan menggunakan sampel $M$. tuberculosis yang dipaparkan dengan $\mathrm{INH} 0,5 \mu \mathrm{g} / \mathrm{ml}$ tidak menunjukkan terjadinya perubahan morfologi pada pemaparan selama 3 jam, perubahan morfologi terjadi setelah 24 jam pada dinding sel yang diamati dengan mikroskop elektron. Dinding sel bakteri dapat mengalami perubahan struktural dinamis selama terpapar obat, sehingga mengurangi sifat resisten terhadap asam yang dapat berfungsi sebagai strategi adaptif untuk bertahan hidup pada inang (Kochi et al., 1993). Pada pengamatan strain mutan, menunjukkan terjadinya penumpukan asam mikolat lebih tinggi di dinding sel bila dibandingkan dengan tipe liar (Lee et al., 1999)

Penelitian ini dilakukan untuk melakukan evaluasi karakteristik $M$. tuberculosis yang terpapar oleh INH dilihat dari morfologi dinding sel, pengecatan Ziehl Neelsen, dan jumlah koloni yang tumbuh untuk mengetahui dampak dari INH terhadap terjadinya perubahan karakteristik secara fenotip.

\section{Materi dan Metode}

Penelitian dilaksanakan Laboratorium Kesehatan Propinsi Jawa Tengah, Laboratorium Struktur dan Perkembangan Hewan Universitas Jenderal Soedirman dan Laboratorium International Tropical Marine and Earth Sciences Laboratory (ITMEL) Universitas Jenderal Soedirman.

Sampel diperoleh dari BKPM Semarang dengan kriteria sampel sputum penderita TB belum mengalami pengobatan, diperoleh hasil mikroskopis BTA dengan hasil minimal +1 , dilakukan kultur pada LJ, dilakukan DST, identifikasi M.tuberculosis

Jenis penelitian eksperimental dengan variasi waktu pemaparan INH yaitu 24 jam, 48 jam, 72 jam dan 96 jam dengan konsentrasi INH $0,5 \mu \mathrm{g} / \mathrm{ml}$ dengan jumlah pengulangan 6 . Variabel bebas lama paparan INH terhadap $M$. tuberculosis, sedangkan variabel terikatnaya pertumbuhan koloni $M$. tuberculosis, morfologi sel dengan pengamatan mikroskopis dan SEM.

Kultur M.tuberculosis pada media LJ selama 5 minggu kemudian dilakukan pemaparan terhadap INH selama 24 jam, 48 jam, 72 jam dan 96 jam kemudian diisolasi pada media Lowenstein Jensen selama 5 minggu dengan suhu $37^{\circ} \mathrm{C}$ dilakukan pengamatan setiap minggu dicatat pertumbuhan koloni selama 5 minggu. Dilakukan uji niacin, katalase tahan panas, dilakukan pengecatan dengan menggunakan pengecatan Ziehl Neelsen, pengecatan Gram diamati dengan mikroskop multimedia Nikon 1000 , processing sampel $M$. tuberculosis untuk pengamatan dengan mikroskop Elektron Hitachi $3000 \mathrm{X}$.

\section{Hasil dan Pembahasan}

Sampel dahak yang diperoleh dari Balai Kesehatan Paru Masyarakat Semarang (BKPM Semarang), dilakukan uji langsung dengan melakukan pembuatan preparat sedian, kemudian dilakukan pengecatan Ziehl Neelsen (ZN), proses kultur dilakukan dengan dekontaminasi $\mathrm{NaOH}$, kemudian ditanam pada media Lowenstein Jensen (LJ) selama 5 minggu, pengamatan pada setiap minggu, setelah tumbuh kemudian dilakukan uji asam $P$ nitrobenzoat (PNB), niacin dan katalase panas untuk menentukan subtipe bakteri. Pemeriksaan sampel A, B, C dan D dengan hasil kultur $3+$, niacin positif, katalase panas negatif, PNB hasil negatif, hal ini menujukkan bahwa bakteri tersebut termasuk subtipe $M$. tuberculosis, selanjutnya dilakukan uji DST INH $0,2 \mu \mathrm{g} / \mathrm{ml}$, hasil yang diperoleh dari sampel $A, B, C$ dan $D$ semua bakteri $M$. tuberculosis sensitif terhadap INH 0,2 $\mu \mathrm{g} / \mathrm{ml}$.

M. tuberculosis diinkubasi pada suhu $37^{\circ} \mathrm{C}$ selama 5 minggu, adapun yang belum menunjukkan pertumbuhan diinkubasi kembali sampai 8 minggu, apa bila tidak ada pertumbuhan dilaporkan sebagai hasil negatif. Pada beberapa sampel terdapat perubahan warna dari biru muda menjadi hijau tua.

\section{Pertumbuhan M. tuberculosis}

Pada penelitian ini pengamatan pertumbuhan dilakukan dengan melakukan inokulasi kembali pada media LJ selama 5 minggu, dilakukan pemeriksaan dengan mikroskop elektron terhadap bakteri yang tumbuh pada media LJ. Pada penelitian pengamatan hasil setelah terpapar $\mathrm{INH} 0,5 \mu \mathrm{g} / \mathrm{ml}$ melalui inokulasi terlebih dahulu, sedangkan penelitian Takayama et al. (1973) pengamatan dilakukan secara langsung setelah dilakukan pemaparan dengan $\mathrm{INH}$.

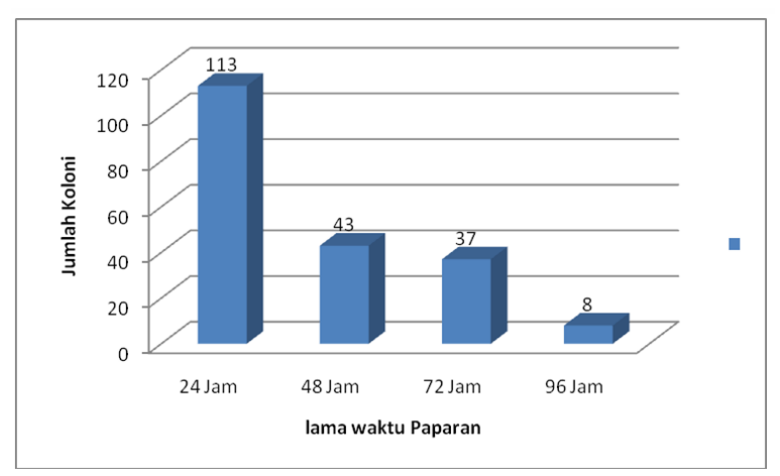

Gambar 1 Pertumbuhan M. tuberculosis yang terpapar $\mathrm{INH} 0,5 \mu \mathrm{g} / \mathrm{ml}$

Pada pengamatan pertumbuhan koloni yang tidak terpapar INH sudah muncul koloni bakteri pada 2 minggu inkubasi, sedangkan pada 
sampel yang dipaparkan dengan INH baru muncul koloni bakteri pada 3 minggu dengan suhu inkubasi $37^{\circ} \mathrm{C}$ suasana aerobe. Pemaparan selama 24 jam koloni bakteri tumbuh sebanyak 113 koloni, pemaparan 48 jam koloni bakteri tumbuh sebanyak 43 koloni, pemaparan selama 72 jam koloni bakteri sebanyak 37 koloni, pemaparan selama 96 jam koloni bakteri 8 koloni.

\section{Ukuran M. tuberculosis}

Pertumbuhan $M$. tuberculosis bervariasi dalam ukuran dan bentuk dari cocco basil ke batang panjang, dengan ukuran sel pada strain H37 subkultur di Columbia University bervariasi dari

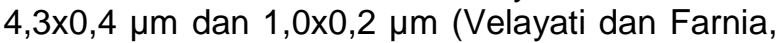
2012). M. tuberculosis menjadi lebih pendek dalam kultur yang lebih tua dan bulat telur saat kondisi kekurangan nutrisi (Shleeva et al., 2011).

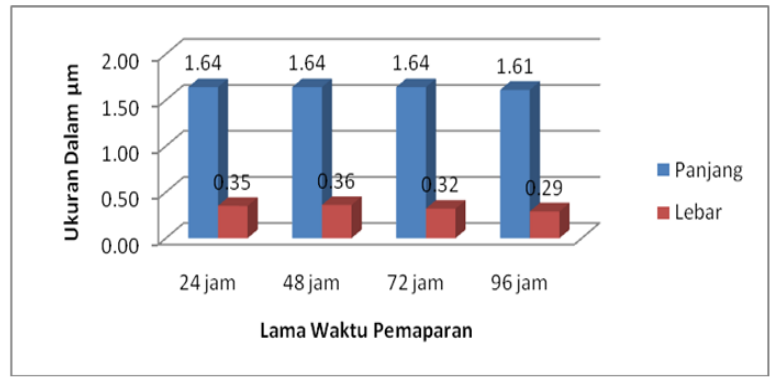

Gambar 2 Ukuran rerata panjang dan lebar Mycobacterium tuberculosis dengan menggunakan mikroskop trinokuler Nikon (Kultur 5 minggu pada media LJ

Hasil pengukuran rerata panjang dan lebar M. tuberculosis pada sampel dahak dengan panjang 2,92 x 0,34 $\mu \mathrm{m}$ setelah dilakukan kultur pada media LJ (sampel TO) ukuran menjadi 1,84 x 0,38 $\mu \mathrm{m}$ ini dikarenakan pada saat pembuatan preparat inkubasi pada media LJ hanya 5 minggu kemudia dilakukan paparan dengan INH konsentrasi $0,5 \mu \mathrm{g} / \mathrm{ml}$ sesuai dengan perlakuan kemudian diinkubasi pada media LJ selama 5 minggu.

Diperoleh hasil pengukuran $M$. tuberculosis pada pemaparan INH selama 24 jam dengan ukuran rerata $1,64 \times 0,35 \mu \mathrm{m}$, lama pemaparan 48 jam ukuran rerata $1,64 \times 0,36 \mu \mathrm{m}$, lama pemaparan 72 jam rerata ukuran 1,64 x 0,32 $\mu \mathrm{m}$, lama pemaparan 96 jam rerata ukuran 1,61 x 0,29 $\mu \mathrm{m}$. INH mempengaruhi pertumbuhan bakteri $M$. tuberculosis Pemberian INH secara in vitro sebanyak $0,5 \mu \mathrm{g} / \mathrm{ml}$ akan mempengaruhi biosintesis asam mikolat lama paparan berkorelasi dengan kerusakan sel pada $M$. tuberculosis dan ukuran panjang bakteri (Takayama et al., 1973).
Tabel 1: Persentase kerusakan M.tuberculosis terpapar INH 0,5 $\mu \mathrm{g} / \mathrm{ml}$

\begin{tabular}{ccc}
\hline Sampel & $\begin{array}{c}\text { persentase } \\
\text { Normal \% }\end{array}$ & $\begin{array}{c}\text { persentase } \\
\text { abnormal \% }\end{array}$ \\
\hline 24 jam & 71.09 .00 & 28.01 .00 \\
48 jam & 59.00 .00 & 41.00 .00 \\
72 jam & 46.06 .00 & 53.04 .00 \\
96 jam & 43.00 .00 & 57.00 .00 \\
\hline
\end{tabular}

M.tuberculosis (H37Rv) sebagai kontrol negatif, He sebagai kontrol positif dan strain kultur $M$. tuberculosis yang semuanya memiliki bentuk $100 \%$ normal, sedangkan pada pemaparan INH selama 24 jam menyebabkan $71,9 \%$ normal dan 28,1 \% abnormal, pemaparan INH selama 48 jam menyebabkan $59,0 \%$ normal dan $41,0 \%$ abnormal, pemaparan INH selama 72 jam menyebabkan 46,0 \% normal dan 53,4 \% abnormal, pemaparan INH selama 96 jam menyebabkan 43,0 \% normal dan 57,0 \% abnormal pengamatan dilakukan dengan mikroskop multimedia Nikon 1000 dengan kriteria sel normal berbentuk batang, ukuran normal, sedangkan kriteria sel abnormal kerusakan pada dinding sel, penyerapan warna tidak maksimal (berwarna pucat), bentuk bengkok dan menyerupai kokus.

\section{Morfologi M. tuberculosis}

M. tuberculosis yang diamati dengan SEM mengalami dua fitur yang berbeda, pertama sel mengalami retakan atau gerakan post fission gerakan yang dikarenakan dinding sel berlapis lapis dimana lapisan dalam membentuk septum sedangkan lapisan luar pecah di satu sisi, fitur kedua terkait dengan pembelahan sel membentuk struktur percabangan sementara (Dahl, 2004).

Gambar 3.A) bakteri berbentuk normal tidak ada yang mengalami kerusakan dinding sel, gambar 3.B) pada kontrol negatif H37RV yang telah disubkultur sebelumnya memiliki bentuk yang normal dengan membentuk diplo basil dan bergerombol, gambar 3.C) pada kontrol positif $\mathrm{HE}$ bentuk normal seragam dengan persebaran merata tidak banyak yang membentuk fragmen, gambar 3.D) pada paparan 24 jam bentuk morfologi mulai ada perubahan salah satunya perubahan ukuran, adanya kerutan pada sel, gambar 3.E) paparan 48 jam banyak dijumpai sel yang rusak pada permukaan dinding sel, adanya sel yang pucat akibat tidak mampu mempertahankan warna merah saat de colorisasi dengan asam, gambar 3.F) pada paparan 72 jam banyak sel yang pucat dan terdapat sel dengan 
bentuk oval, gambar 3.G) pada paparan 96 jam M.tuberculosis berbentuk kokus dengan sifat resisten terhadap $\mathrm{INH}$, gambar $3 . \mathrm{H}$ ) generasi ke dua dari paparan 96 jam perubahan morfologi yang awalnya banyak dijumpai bentuk kokus dan mulai ber agam bentuk sel dengan mempertahankan warna merah lebih kuat.
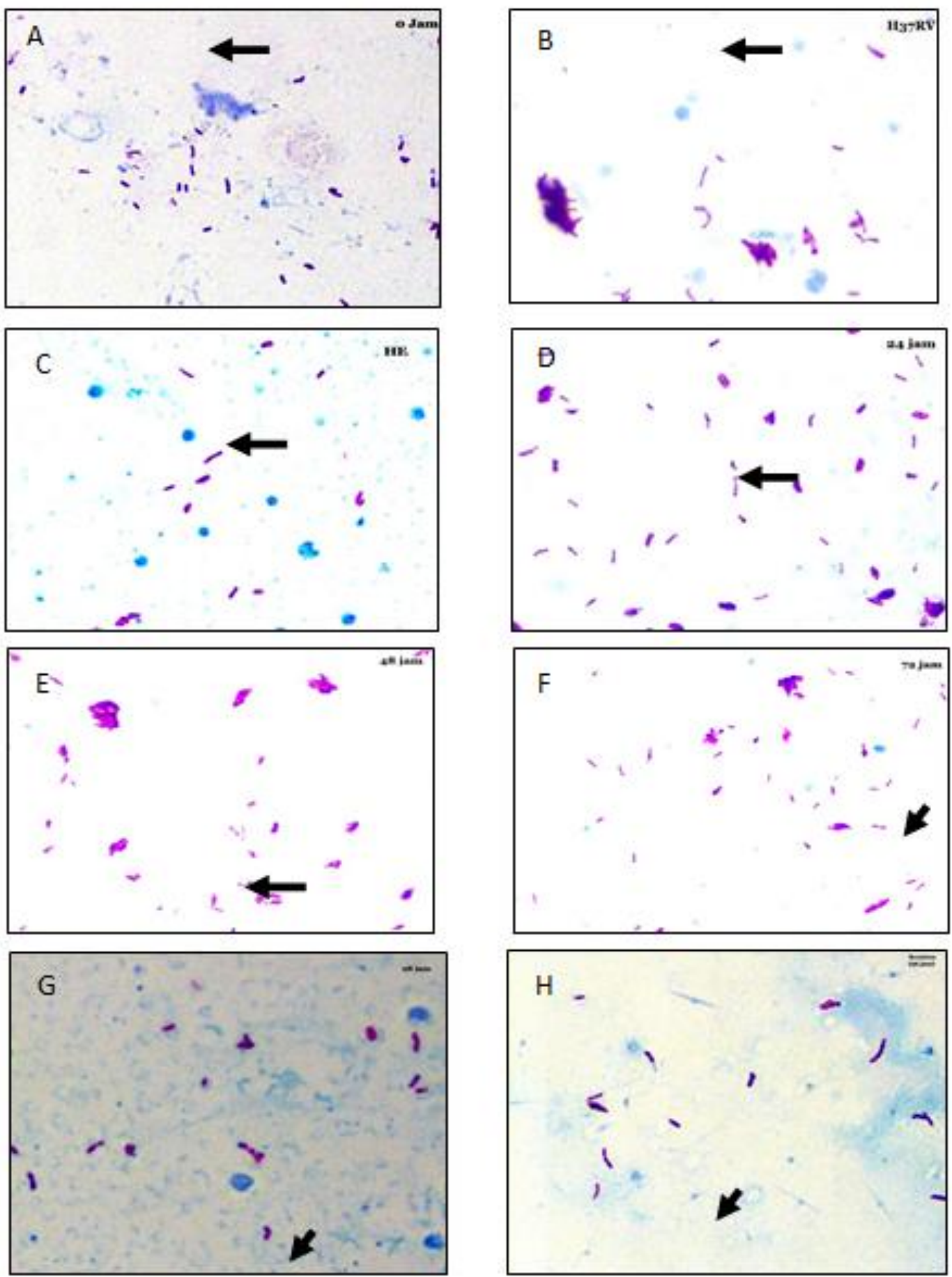

Gambar 3. Morfologi M. tuberculosis pengecatan Ziehl Neelsen, (pengamatan perbesaran $1000 \mathrm{X}$ mikroskop trinokuler a) Tanpa terpapar obat, b) sebagai kontrol Strain $M$. tuberculosis $(\mathrm{H} 37 \mathrm{Rv})$, c) Kontrol Resistensi INH dan Entabuntol (HE), d) terpapar INH 24 jam, e) terpapar INH 48 jam, f) terpapar INH 72 jam, g) terpapar INH 96 jam, h) Resistensi dari proses pemaparan. 

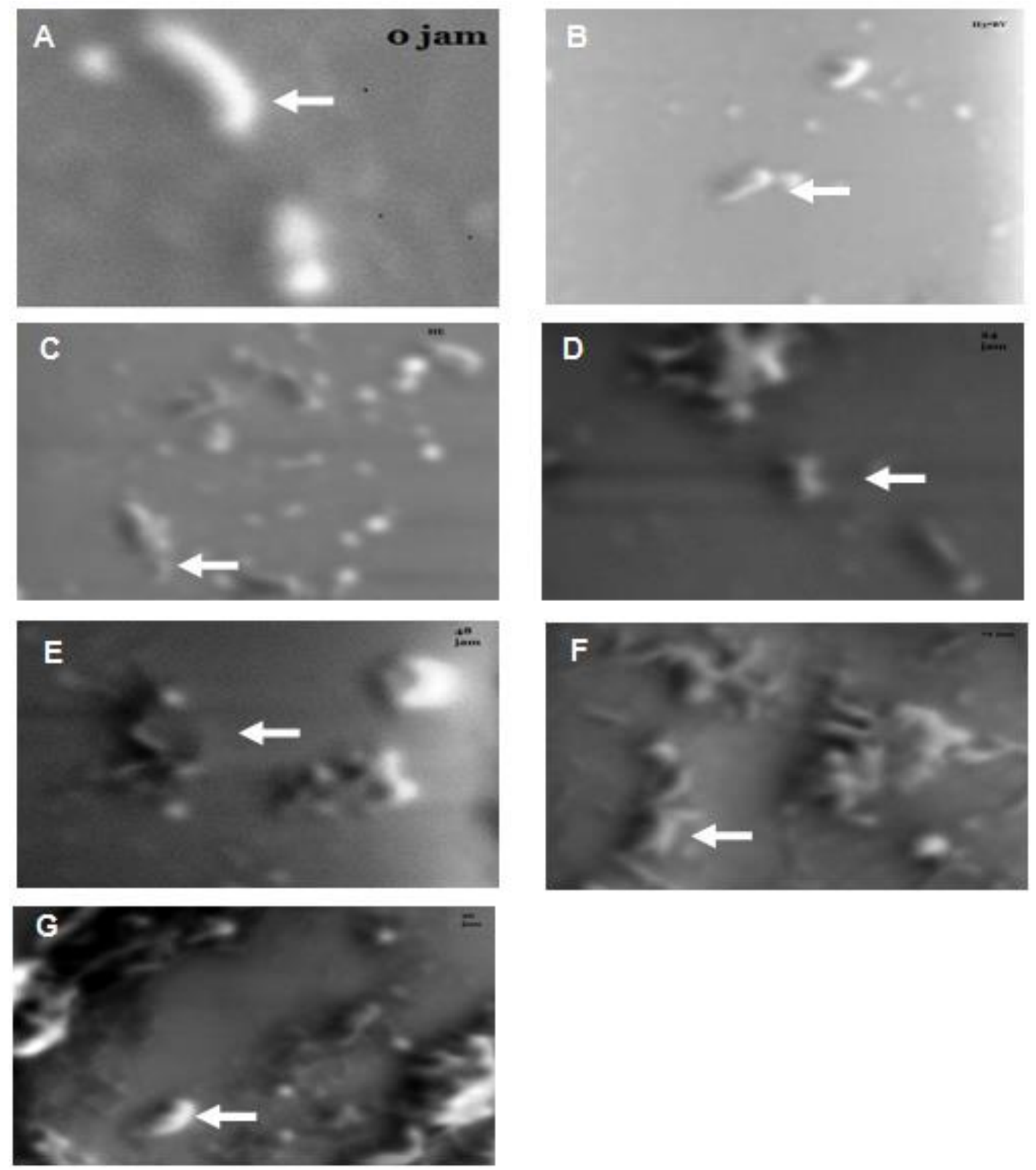

Gambar 4. Morfologi M. tuberculosis (scanning microscope elektron perbesaran 10.000 X) A. tanpa ada perlakuan, B. Kontrol negative merupakan $M$. tuberculosis Strain H37Rv tanpa ada perlakuan Obat INH , C. Kontrol positif merupakan M. tuberculosis yang telah terhadap resistensi INH dan Entambutol (HE), pemaparan Isoniazid 0,5 $\mathrm{\mu g} / \mathrm{ml}$ pada D. Terpapar 24 jam , E terpapar 48 jam, F. Terpapar 72 jam, G. Terpapar 96 jam

Gambar 4. A) menujukkan sel yang belum mengalami paparan $\mathrm{INH}$ dengan bentuk batang, gambar 4.B) menunjukkan kontrol negatif dari H37RV dengan bentuk sel normal tidak ada kerusakan pada permukaan sel, gambar 4.C) kontrol Positif HE dengan hasil pengamatan bentuk sel normal banyak dijumpai sel dengan ukuran kecil. Gambar 4.D) waktu paparan INH selama 24 jam terlihat adanya sedikit kerutan pada dinding sel yang diperlihatkan dengan anak panah warna merah, gambar 4.E) waktu paparan 48 jam dijumpai sel dengan bentuk bulat dan menggerombol bentuk sel tak beraturan, gambar
4.F) waktu paparan 72 jam ditemukan sel dengan bentuk ujung bercabang seperti huruf $\mathrm{Y}$, bentuk sel beragam didominasi bentuk batang, gambar 4.G) waktu paparan 96 jam dijumpai sel pada bagian ujung membentuk bulat dan sel dengan bentuk bulat mendominasi. Hasil pengamatan bentuk sel beragam ada yang mengalami percabangan pada bagian ujung sel, ada yang mengalami pematahan pada salah satu sisi sel, bentuk sel ada yang membengkok ke kanan maupun ke kiri, banyak dijumpai ukuran dibawah normal. Pada paparan selama 96 jam persentase kerusakan mencapai $57 \%$ dengan dominasi 
bentuk sel yang menyerupai kokus berantai, kerusakan dapat terlihat jelas pada pengamatan SEM dengan adanya patahan pada bagian sel, dijumpai serpihan sel yang mengalami lisis, pada pengecatan ZN terdapat perubahan bentuk sel ke arah kokus tiap sel terdiri dari 2 sampai 3 sel.

lama papran terhadap bentuk dinding sel M. tuberculosis setelah 24 jam dipaparkan menunjukan gambaran morfologi mulai beragam dengan urutan perubahan morfologi sebagai berikut : 1. Terjadi kerutan pada permukaan sel penyusutan panjang setelah regenerasi, 2 . Permukaan sel mulai kasar dan sedikit ada kerusakan, 3. Sitoplasma mulai dikeluarkan dari sel, 4. Sel mengalami perubahan bentuk dari batang menjadi kokus.

Selubung pada $M$. tuberculosis memiliki tiga komponen penyusun yaitu struktur plasma membran, dinding dan kapsul. Pelasma membran memainkan peran dalam proses patologis, dinding menyerupai dinding gram positif tetapi memiliki lapisan lipid ester mikolat yang semua komponennya mempunyai peran penting dalam fisiologi dan patogenesitas (Daffe dan Draper, 1997).

Hilangnya L,D transpeptidase 1 dan 2 dari M. tuberculosis (LdtMt dan LdtMt2) mampu merubah morfologi permukaan sel, bentuk, ukuran, matrik seluler, pengaturan beberapa protein dengan berat molekul rendah yang ditujukan ke membran atau keluar sel, mempengaruhi pertumbuhan, virulensi dan ketahan $M$. tuberculosis untuk amoxicillin clavulanate dan vancomycin (Schoonmaker et al., 2014).

Mekanisme penetrasi molekul kecil kedalam sel $M$. tuberculosis melalui selubung sel yang terdiri membran plasma, dinding dan kapsul secara struktural berbeda dari Gram positif dan Gram negatif, seluruh selubung sel mycobacteria dapat dipecah menjadi dua komponen utama yaitu struktur membran sel dan dinding sel. Dinding sel terdiri dari asam mikolat yang kovalen dengan kompleks arabinogalactan, peptidoglikan. Mycobacteria mampu menghasilkan banyak asam mikolat dengan berbagai ukuran panjang dan modifikasi tergantung spesies dan kondisi pertumbuhan (Daffe dan Draper, 1997 ; Barry et al, 2007).

Pengunaan fuksin pada pewarnaan $M$. tuberculosis dengan konsentrasi 0,3\% akan mengurangi sensitivitas, tetapi penggunaan fuksin diatas 0,3\% memiliki sensitivitas yang sama hanya menggunakan reagen yang lebih banyak (Selvakumar et al., 2005). Morfologi di M. tuberculosis diklasifikasikan ke dalam dua kategori sel - sel tersebut sering terlihat pada fase eksponensial pertumbuhan yang batang, V, $Y$ atau bercabang dan bila dalam kondisi stress atau lingkungan yang kurang menguntungkan berbentuk bulat, oval, atau bengkok menyerupai huruf L (Velayati dan Farnia, 2012 ; Dahl, 2004).

$M$. tuberculosis selama pembentukan septum membran plasma dan dinding sel bagian dalam tumbuh ke dalam lapisan dinding sel luar tetap utuh. Setelah menyelesaikan pembentukan septum lapisan dalam mungkin terus tumbuh memberikan tekanan pada lapisan luar dinding sel, selanjutnya akan terbentuk 2 sel anak (Dahl, 2004 ; Malhotra et al., 2010). Cabang pertama kali terlihat sebagai tunas kecil setelah tumbuh akan melepaskan diri sebagai sel terpisah. pada penelitian ini paparan selama 96 jam $57 \%$ sel berbentuk bulat, oval dikarenakan pengaruh adaptasi terhadap INH $0,5 \mu \mathrm{g} / \mathrm{ml}$ kondisi ini akan kembali seperti semula bila faktor yang mempengaruhi telah dihilangkan.

\section{Simpulan}

Berdasarkan hasil penelitian karakteristik M. tuberculosis yang terpapar INH $0,5 \mu \mathrm{g} / \mathrm{ml}$ diperoleh kesimpulan : (1). Terjadi penurunan jumlah sel dan pertumbuhan koloni sel yang tanpa paparan INH muncul pada 2 minggu inkubasi, sedangkan pada sel yang terpapar INH muncul koloni pada 3 minggu inkubasi pada suhu $37^{\circ} \mathrm{C}$ suasana aerobe, dan (2). Terjadi kerutan pada permukaan sel, penyusutan panjang sel setelah regenerasi, Permukaan sel mulai kasar dan sedikit ada kerusakan, sitoplasma mulai dikeluarkan dari sel, sel mengalami perubahan bentuk dari batang menjadi kokus.

\section{Daftar Referensi}

Dahl, J. L. 2004. Electron microscopey analysis of Mycobacterium tuberculosis cell division. FEMS Microbiology Letters. 240 (1) : 15-20.

Jarlier, V., and Nikaido, H. 1994. Mycobacterial cell wall: structure and role in natural resistence to antibiotics. FEMS Microbiology Letters. 123(1-2), 11-18.

Kochi, A., Vareldzis, B., and Styblo, K. 1993. Multidrug-resisten tuberculosis and its control. Research in Microbiology. 144(2): 104-110.

Larrouy-Maumus, G., Marino, L. B., Madduri, A. V., Ragan, T. J., Hunt, D. M., Bassano, L., Gutierrez, M.G., Moody, D.B., Pavan, F. R., and de Carvalho, L. P. S. 2016. CellEnvelope Remodeling as a Determinant of Phenotypic Antibacterial Tolerance in Mycobacterium tuberculosis. ACS Infectious Diseases. 2(5): 352-360.

Lee, A. S., Lim, I. H., Tang, L. L., Telenti, A., and Wong, S. Y. 1999. Contribution of kasA Analysis to Detection of isoniazid-Resisten 
Mycobacterium tuberculosis in Singapore. Antimicrobial Agents and Chemotherapy. 43(8): 2087-2089.

Malhotra, D., Portales-Casamar, E., Singh, A., Srivastava, S., Arenillas, D., Happel, C., .and Biswal, S. 2010. Global mapping of binding sites for Nrf2 identifies novel targets in cell survival response through ChIP-Seq profiling and network analysis. Nucleic Acids Research. 38(17): 5718-5734.

Ramaswamy, S. V., Reich, R., Dou, S. J., Jasperse, L., Pan, X., Wanger, A., Quitugua, T., and Graviss,A, 2003. Single nucleotide polymorphisms in genes associated with isoniazid resistence in Mycobacterium tuberculosis. Antimicrobial Agents and Chemotherapy. $47: 1241-1250$.

Rattan, A., Kalia, A., and Ahmad, N. 1998. Multidrug - resisten Mycobacterium tuberculosis : molecular perspectives Emerging Infectious Diseases. 4(2) : 195 209.

Rawat, R., Whitty, A., and Tonge, P. J. 2003. The isoniazid-NAD adduct is a slow, tight-binding inhibitor of InhA, the Mycobacterium tuberculosis enoyl reductase: adduct affinity and drug resistence. Proceedings of the National Academy of Sciences. 100(24): 13881-13886.

Schoonmaker, M. K., Bishai, W. R., and Lamichhane, G. 2014. Nonclassical transpeptidases of Mycobacterium tuberculosis alter cell size, morphology, the cytosolic matrix, protein localization, virulence, and resistence to $\beta$-lactams. Journal of Bacteriology. 196(7): 1394-1402.

Selvakumar, N., Gomathi Sekar, M., Rahman, F., Syamsunder, A., Duraipandian, M., Wares, F., and Narayanan, P. R. 2005. Comparison of variants of carbol-fuchsin solution in ZiehlNeelsen for detection of acid-fast bacilli [Technical Note]. The International Journal of
Tuberculosis and Lung Disease. 9(2): 226229.

Shleeva, M.O., Kudykina, Y.K., Vostroknutova, G.N., Suzina, N. E., Mulyukin, A. L., and Kaprelyants, A. S. 2011. Dormant ovoid cells of Mycobacterium tuberculosis are formed in response to gradual external acidification. Tuberculosis. 91 (2): $146-154$.

Takayama, K., Wang, L., and David, H. L. 1973. Effect of isoniazid on the in vivo mycolic acid synthesis, cell growth, and viability of Mycobacterium tuberculosis. Antimicrobial Agents and Chemotherapy. 2(1): 29-35.

Thanky, N. R., Young, D. B., and Robertson, B. D. 2007. Unusual features of the cell cycle in mycobacteria: polar-restricted growth and the snapping-model of cell division. Tuberculosis. 87(3): 231-236.

Velayati, A.A., and Farnia,P. 2012. Morphological Characterization of mycobacterium tuberculosis. INTECH Open Access Publisher.

http://www.interchopen.com/books/understan ding-tuberculosis diakses 10 Agustus 2016.

Youatt, J. 1969. A Review of the Action of isoniazid 1. American Review of Respiratory Disease. 99(5): 729-749.

Zhang, Y., Garbe, T., and Young, D. 1993. Transformation with Kat $\mathrm{G}$ restores isoniazidsensitivity in Mycobacterium tuberculosis isolates resisten to a range of drug concentrations. Molecular Microbiology. 8(3): 521-524.

Zhang, Y., and Yew, W. W. 2009. Mechanisms of drug resistence in Mycobacterium tuberculosis [State of the art series. Drugresisten tuberculosis. Edited by CY. Chiang. Number 1 in the series]. The International Journal of Tuberculosis and Lung Disease. 13(11): 1320-1330 